\title{
Defense Gene Expression Associated with Biotrophic Phase of Mycosphaerella fijiensis M. Morelet Infection in Banana
}

\begin{abstract}
Hector A. Rodriguez, Plant Biotechnology Unit UNALMED-CIB, Corporación para Investigaciones Biológicas, Carrera 72a Number 78b-141, Medellín Colombia; and Departamento de Ciencias Agronómicas, Facultad de Ciencias Agrarias, Universidad Nacional de Colombia sede Medellín, Calle 59A Number 63-20, Medellín, Colombia; Esperanza Rodriguez-Arango, Plant Biotechnology Unit UNALMED-CIB, Corporación para Investigaciones Biológicas; Juan G. Morales, Departamento de Ciencias Agronómicas, Facultad de Ciencias Agrarias, Universidad Nacional de Colombia sede Medellín; Gert Kema, Biointeractions \& Plant Health, Plant Research International, Wageningen, The Netherlands; and Rafael E. Arango, Plant Biotechnology Unit UNALMED-CIB, Corporación para Investigaciones Biológicas; and Escuela de Biociencias, Facultad de Ciencias, Universidad Nacional de Colombia sede Medellín
\end{abstract}

\begin{abstract}
Rodriguez, H. A., Rodríguez-Arango, E., Morales, J. G., Kema, G., and Arango, R, E., 2016. Defense gene expression associated with the biotrophic phase of Mycosphaerella fijiensis M. Morelet infection in banana. Plant Dis. 100:1170-1175.

Banana black leaf streak, caused by Mycosphaerella fijiensis M. Morelet, is a primary phytosanitary concern in export of this fruit around the world. To develop improved cultivars resistant to this disease, an understanding of host response to infection is necessary. In this study, we obtained expression data on 14,872 genes by microarray analysis in the resistant genotype Musa acuminata subsp. burmannicoides 'Calcutta 4' after inoculation with Mycosphaerella fijiensis. From these data, 16 genes were analyzed as potential reference genes and 12 genes were identified as potential early indicators of the onset of the host defense response. Subsequently, these genes were analyzed by quantitative reverse-transcription polymerase chain reaction in susceptible

'Williams' and resistant Calcutta 4. The $18 \mathrm{~S}$ and 26S ribosomal subunit genes in both cultivars showed the best characteristics as reference genes. In all, 5 of the 12 defense genes expressed shortly after infection (peroxidase, pathogenesis-related [PR]-4, PR-10, phenylalanine ammonia-liase, and disease resistance response 1) showed overexpression in Calcutta 4 between 6 and $24 \mathrm{~h}$ after inoculation as opposed to Williams, which did not show overexpression after $144 \mathrm{~h}$. Early induction of defense-related genes could be a key component of the resistance of the Calcutta 4 genotype against $M$. fijiensis. In addition, these five genes could be used as indicators of the activation of defense responses in the interaction between banana and M. fijiensis.
\end{abstract}

Economically, the most important disease in banana and plantain crops is black leaf streak, also known as black Sigatoka, caused by the fungus Mycosphaerella fijiensis M. Morelet. Worldwide, $\$ 550$ million dollars is spent annually to control this disease (Churchill 2011). Nevertheless, $M$. fijiensis adapts quickly and effectively to the fungicides used for its control, a situation which makes the future of the banana industry vulnerable to diseaseinduced crop losses.

M. fijiensis belongs to the Dothideomycetes class and has a hemibiotrophic life cycle. Under greenhouse conditions, infection begins with spore deposition on the leaf, followed by germination within $6 \mathrm{~h}$ and leaf penetration by germ tubes via stomata within 12 to $15 \mathrm{~h}$ (Vasquez et al. 1990). Once inside the leaf, hyphae grow through the mesophyll layers and into the palisade tissue (Meredith 1970; Stover 1980). Cytological studies of the interactions between $M$. fijiensis and the susceptible banana cv. Grande Naine have shown 22 days of biotrophic phase after infection before necrotic spots are observed. During this period, little evidence of disease is observed externally (Vasquez et al. 1990). The molecular mechanisms of infection by $M$. fijiensis are poorly understood; however, genomic analyses of this pathogen reveal the presence of effector proteins such as MfAVR4 that show characteristics typical of other effectors in related pathogens such as Cladosporium fulvum Cooke (Ohm et al. 2012; Stergiopoulos et al. 2013).

Corresponding author: R. E. Arango; E-mail: rarango@ cib.org.co

*The $\boldsymbol{e}$-Xtra logo stands for "electronic extra" and indicates that two supplementary tables are published online.

Accepted for publication 6 January 2016.

http://dx.doi.org/10.1094/PDIS-08-15-0950-RE

(c) 2016 The American Phytopathological Society
Black-leaf-streak-resistant genotypes of banana showed accumulation of phenolic compounds and presence of specialized polyphenolstoring cells in parenchyma (Cavalcante et al. 2011). Recent studies have shown that there is a rapid induction of phenylalanine ammonia-lyase (PAL), peroxidase (POX), and $\beta$-1,3-glucanase activity in the resistant variety Calcutta 4 within the first $72 \mathrm{~h}$ after infection, in contrast to a later induction of these enzymes in the susceptible cv. Williams (Torres et al. 2012). In Calcutta 4, increased expression of genes coding for the pathogenesis-related (PR) proteins PR-1, PR-2, PR-3, PR-4, PR-9, PR-10, PR-14, and PR-15 was observed during the interaction with M. fijiensis (Portal et al. 2011; Rodriguez-Cabal 2012).

The relatively recent publication of the banana genome identified numerous genes encoding putative proteins related to the components of pathogen-associated molecular pattern-triggered immunity and effector-triggered immunity, suggesting that the response mechanisms observed in other monocots and dicots are conserved in Musa spp. (D'Hont et al. 2012). Even with this information, studies on the banana- $M$. fijiensis interactions at the molecular level are incomplete, particularly early in the infection process.

Gene expression analysis is important for the identification of genes involved in plant-pathogen interactions. These analyses, however, require identification of useful reference genes. Reference genes are constitutively expressed and are required for the maintenance of basic cell functions. In the analysis of induced gene expression, reference genes are used to determine the level of the target gene expression relative to the constitutive level of gene expression.

In addition, due to the long biotrophic incubation period of $M$. fijiensis infection, it is also very important to study the dynamics of induction of defense-related genes during the biotrophic phase of infection in susceptible and resistant genotypes. In this study, we used a microarray assay containing 14,872 banana genes to study early interactions between $M$. fijiensis in the resistant genotype Musa acuminata subsp. burmannicoides Calcutta 4. Several genes were selected as good candidates as reference genes, while other sets of defense-related genes were identified as being induced in the 
resistant genotype in early stages of infection. The expression profiles of selected genes were further tested by real-time polymerase chain reaction (PCR) in both the resistant Calcutta 4 and the susceptible Williams.

\section{Materials and Methods}

Plant material. Black-leaf-streak-susceptible Williams (triploid, AAA genome group) plants were obtained from the in vitro culture facilities of the Plant Biotechnology Unit Universidad Católica de Oriente, Rionegro, Colombia. Resistant Calcutta 4 (diploid, AA genome group) plants were obtained from University of Caldas, Colombia. Two-month-old plants were kept under greenhouse conditions at $29^{\circ} \mathrm{C}$ and relative humidity (RH) above $95 \%$ with standard fertilization and irrigation practices until inoculation.

Mycosphaerella fijiensis strains. Monoascosporic strains of Mycosphaerella fijiensis were obtained from banana leaves collected in the Urabá region (Department of Antioquia, Colombia), as previously described by Mira (2004). Single-ascospore isolates were grown on potato dextrose agar (Difco, Becton Dickinson, Franklin Lakes, NJ) and incubated at $25 \pm 1^{\circ} \mathrm{C}$ until a colony of about $1 \mathrm{~cm}$ in diameter was obtained.

Inoculation of banana with mycelial fragments of $M$. fijiensis was performed as reported by Alvarez et al. (2013). After inoculation, plants were kept in an infection chamber at constant temperature of $29^{\circ} \mathrm{C}, \mathrm{RH}$ of $95 \%$, and $12 \mathrm{~h}$ of light and $12 \mathrm{~h}$ of darkness. Inoculation experiments were repeated three times. Three leaf-disk samples (approximately $10 \mathrm{~cm}$ in diameter) per plant from two different plants were collected at $0,6,12,18,24,72$, and $144 \mathrm{~h}$ after inoculation (hai). The six samples collected at each time point were pooled and used for RNA extraction.

RNA isolation and cDNA synthesis for microarrays. Total RNA was extracted from banana leaves of 2-month-old plants using the Small Scale RNA Isolation kit (Invitrogen, Grand Island, NY) according to the manufacturer's instructions. RNA concentration was measured at $260 \mathrm{~nm}$, using a NanoDrop ND-1000 UV-Vis Spectrophotometer (NanoDrop Technologies, Thermo Fisher, Wilmington, DE). DNAse I (Thermo Scientific, Wilmington, DE) was used to treat $800 \mathrm{ng}$ of RNA, which was further purified using MinElute Cleanup columns (Qiagen, Redwood City, CA). The quality of RNA was verified with the RNA Integrity Number algorithm through the 2100 Bioanalyzer Instrument (Agilent, Waldbronn, Germany). The RNAs were assayed for genomic DNA contamination by PCR using primer set $\beta$-ActinaBanano-Fw 5'-CAAGGAAAAGCTTGCC TACG- ${ }^{\prime}$ and $\beta$-ActinaBanano-Rv $5^{\prime}$-CCTCCATGCCAATCAGA GAT-3' (Alvarez et al. 2013). PCR products were separated by electrophoresis in $1 \%$ agarose gels containing ethidium bromide $(0.5 \mu \mathrm{g} / \mathrm{ml})$ and visualized under ultraviolet light. First-strand cDNA was synthesized using a TransPlex Whole Transcriptome Amplification kit, which uses a random 3' degenerate primer approach (Sigma-Aldrich, St. Louis). Kit procedures were done according to the manufacturer's instructions. Before microarray analysis, the quality of cDNA was evaluated as a service at the company Roche NimbleGen, following the company protocols (Roche NimbleGen, Inc., Madison, WI).

Microarray design and data analysis. Design and synthesis of oligonucleotides, cDNA hybridization, and plate scanner were performed following protocols developed by NimbleGen. For the microarray procedure, the time points $0,24,72$, and 144 hai were analyzed. Each of these times was run in triplicate for a total of 12 microarray hybridizations. Probe design was conducted with 14,872 banana unigene sequences and four probes were selected for each target gene. Each cDNA sample $(1 \mu \mathrm{g})$ was sent to the NimbleGen Company (Roche NimbleGen, Inc.) for microarray processing and gene expression quantification. The minimum information for a microarray experiment (MIAME) guidelines reported by Brazma et al. (2001) and the related version, MIAME/PLANT 2006 (Zimmermann et al. 2006), were considered during all steps of the microarray design, run, and analysis.

Microarray data analysis was performed using Bioconductor, version 2.11 computing software (Gentleman et al. 2004). The computational program PdInfoBuilder (Falcon et al. 2009) was used to create an annotation package compatible with the Oligo package software (Carvalho and Irizarry 2010), which was used to perform the normalization process, with the robust multichip average algorithm applied to the raw data of expression arrays (Bolstad et al. 2003). The Limma computational package was used for gene expression quantification (Smyth 2004). The hierarchical clustering was performed using Multiple Array Viewer Software (version 4.8.1; Dana-Farber Cancer Institute, Boston) (Saeed et al. 2003).

Validation of candidate reference and defense onset genes. Expression of reference and defense-related genes was determined by quantitative reverse-transcription (qRT)-PCR during the interaction of susceptible Williams and resistant Calcutta 4 by $M$. fijiensis. Oligonucleotide primer pairs that allow the amplification of a fragment of approximately $150 \mathrm{bp}$ were designed for each selected gene using the Primer3 software (Rozen and Skaletsky 2000), and their specificity was verified by doing a blast search in the GenBank database (Supplementary Table S1).

RNA was isolated and purified as described for the microarray procedure, and first-strand cDNA was synthesized by oligo(dT) ${ }_{20}$ priming using SuperScript III (Invitrogen, Carlsbad, CA) according to the manufacturer's instructions. Synthesized cDNA was used to perform fluorescence-based real-time PCR quantification using the Maxima SYBR Green qPCR Master Mix (2x) Kit (Thermo Scientific) following the manufacturer's instructions in a CFX96 Touch Real-Time PCR Detection System (Bio-Rad, Foster City, CA). PCR conditions were denaturation at $95^{\circ} \mathrm{C}$ for $30 \mathrm{~s}$, annealing at $60^{\circ} \mathrm{C}$ for $20 \mathrm{~s}$, and elongation at $72^{\circ} \mathrm{C}$ for $30 \mathrm{~s}$ for 35 cycles. The reaction was then incubated for $3 \mathrm{~s}$ at $2^{\circ} \mathrm{C}$ lower than the melting temperature of the DNA fragment. Annealing temperature was selected based on the lack of appearance of nonspecific bands and absence of dimers in the melt-curve analysis. RNA was isolated from plants different from those used for the microarray experiments. For each sample, two independent biological repetitions were analyzed with three technical replicates. The expression ratio was calculated using the $\Delta \Delta$-cycle threshold (Ct) method, assuming an efficiency of 2 (Pfaffl 2001).

For determination of useful reference genes, expression data were analyzed using BestKeeper software (Gene Quantification, Munich, Germany), with the Pearson correlation coefficient and regression analysis (Pfaffl et al. 2004). For defense-related candidate genes, differences in expression throughout the time point series analysis for each gene were calculated in-group means for statistical significance by a pairwise fixed reallocation randomization test using the Relative Expression Software Tool, version 2009 (Gene Quantification, Munich, Germany) (Pfaffl et al. 2002).

\section{Results}

Disease development. After inoculation, diseased and control plants were maintained under the conditions mentioned for 45 days to verify macroscopic symptoms, which were seen as necrosis in the susceptible cultivar and a hypersensitive reaction in the resistant cultivar. In Calcutta 4 and Williams mock-inoculated controls, no symptoms were observed during the time period tested. At 6 days after inoculation, small specks were identified in both cultivars; however, Williams exhibited a higher number than Calcutta 4, corresponding to stage 1 (Fouré 1987). At 15 days after inoculation, about 40 to $50 \%$ of the leaf was covered by disease spots in Williams, in contrast to Calcutta 4, where the leaf area showing symptoms was about 25 to $30 \%$ (stages 4 and 3, respectively). No further disease development was identified for Calcutta 4 at 30 days after inoculation, suggesting that disease development stopped. In clear contrast, fast disease progress with extensive necrosis due to coalescence of lesions was observed for Williams at 30 days after inoculation, reaching stage 6 of disease development (Fouré 1987) (Fig. 1).

Microarray results. In total, 14,872 Musa acuminata Colla gene sequences were evaluated at different time points performed at 0,24 , 72, and 144 hai. In all, 1,173 differentially expressed genes were identified at $24 \mathrm{~h}$, of which 382 were upregulated and 791 were downregulated. At $72 \mathrm{~h}, 1,854$ genes were found differentially expressed, (797 upregulated and 1,057 downregulated) and, at $144 \mathrm{~h}$, 309 genes were upregulated and 815 genes were downregulated. 
Reference gene selection. Based on literature reports from Musa spp. and other plants (Supplementary Table S2), 16 genes were selected as candidate reference genes. Average gene expression values and corresponding standard deviations were calculated for each gene from three repetitions for each microarray. Using data obtained, the best housekeeping reference candidates were selected following two criteria: (i) genes expressed constitutively over the time course of the host-pathogen interaction and (ii) gene expression showing a standard deviation value $<0.8$ at all times examined. This analysis revealed 16 potential reference genes in Calcutta 4 , from which genes coding for actin, glyceraldehyde-3-phosphate dehydrogenase (GADPH), 18S ribosomal subunit, and $26 \mathrm{~S}$ ribosomal subunit had values close to 0 -fold expression (0.099-, 0.025-, -0.068-, and 0.026-fold, respectively) in inoculated plants compared with the noninoculated control for all time points tested. Additionally, these genes exhibited the lowest standard deviations among all the genes analyzed (Fig. 2).

These four genes were selected for further analysis using qRTPCR to compare their expression in resistant Calcutta 4 banana and susceptible Williams banana. The BestKeeper software was used to determine variation between the $\mathrm{Ct}$ values obtained from the qRTPCR at $0,6,12,18,24,72$, and 144 hai time points in the two cultivars. Expression of GADPH and 18s ribosomal RNA had the lowest standard deviation values in both cultivars: 0.7 and 0.5 , respectively

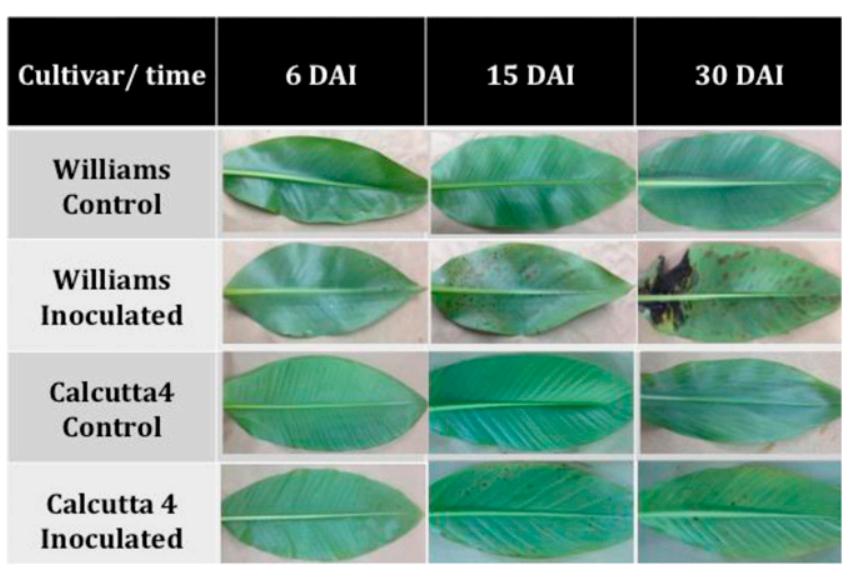

Fig. 1. Symptom development after infection with Mycosphaerella fijiensis M. Morelet in susceptible banana Williams in comparison with resistant Calcutta 4. Monoascosporic strains were inoculated on 2-month-old banana plants. Inoculated plants were incubated at constant temperature of $29^{\circ} \mathrm{C}$, relative humidity of $95 \%$, and $12 \mathrm{~h}$ of light and $12 \mathrm{~h}$ of darkness. Water-gelatin $(2 \%)$ mock-inoculated plants were used as controls. Inoculation experiments were repeated three times. The diseased plants with their respective noninoculated control were photographed 6,15 , and 30 days after inoculation. Photographs represent disease development from 12 leaves on average. in Calcutta 4 and 0.6 and 0.8, respectively, in Williams (Table 1). Expression of the $\beta$-actin gene showed higher variation (standard deviation $>1.8$ crossing point $[\mathrm{Cp}]$ ) compared with the other three genes, which made this gene not useful as a reference for gene expression studies.

In both banana varieties, Pearson correlation coefficients were higher for genes 18S and 26S than for GADPH; however, expression of all three genes compared with each other was $0.513<r<0.888$ (Table 2). GADPH had a good correlation with the other two genes in Williams but not in resistant Calcutta 4. Regression analysis showed results similar to those obtained with the correlation analysis (Table 2). The 18S and 26S genes showed the best correlation coefficient for both banana cultivars.

Identification of defense-response genes. Twelve early-onset banana defense candidate genes were selected from the microarray data as good candidates for defense response indicator genes following two criteria: (i) commonly studied and cited in the literature of Musa spp. and other plant pathosystems and (ii) highly expressed during the early biotrophic phase of the interaction between resistant $\mathrm{Cal}-$ cutta 4 and Mycosphaerella fijiensis (Torres et al. 2012). In all, 9 of the 12 defense-related response genes identified from the microarray analysis were significantly upregulated at 24 hai (Fig. 3). Disease resistance response (DRR)1, DRR2, PR-1, PR-5, and PAL showed the highest levels of relative gene expression $(10.92,5.66,5.27$, 3.9 , and 3.89, respectively) at 24 hai. Catalase and PR-3 genes were upregulated at 72 hai (relative gene expression values of 2.94 and 2.04 , respectively). At 144 hai, genes for DRR2 and the heat shock protein were significantly $(P<0.05)$ upregulated (relative expression value of 4.81 and 4.13, respectively; Fig. 3). Additionally, genes for POX, PR-2, and PR-4 were induced significantly $(P<0.05)$ at 24 hai (relative gene expression values of 2.6, 2.47, and 2.42, respectively).

Validation of defense-response genes for expression analysis by qRT-PCR. Five genes differentially expressed in the microarray analysis (POX, PR-4, PR-10, PAL, and DRR1) were chosen for qRTPCR analysis in resistant Calcutta 4 and susceptible Williams (Fig. 4). At 18 and 24 hai, DRR1, PAL, and PR-10 were upregulated in Calcutta 4, while POX and PR-4 had an earlier upregulation at 6 and 12 hai in the same cultivar. In contrast, all of these genes were downregulated in susceptible Williams (Fig. 4).

\section{Discussion}

Black leaf streak development in banana is characterized by a relatively long, symptomless biotrophic period that makes it difficult to identify the time of onset of defense responses in an infected plant. Therefore, identification of genes that indicate this onset of defense is important for further efforts to better understand the Musa spp.-M. fijiensis interaction, and for designing new disease control strategies such as the identification of defense-inducing compounds or the selection of resistant genotypes. In this article, we identified

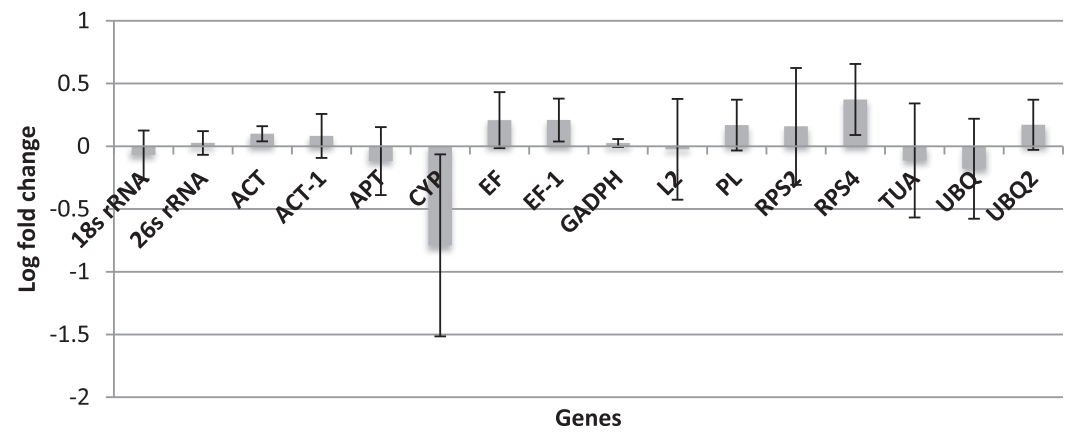

Fig. 2. Expression values of 16 constitutively expressed reference genes in banana during, before, and after inoculation with the fungal pathogen Mycosphaerella fijiensis M. Morelet. Expression data were obtained from microarray expression analysis. Error bars represent the standard deviation of log-transformed gene-expression values, which were derived from three biological replicates sampled at each of four sampling times. $18 \mathrm{~s} r \mathrm{RNA}=18 \mathrm{~s}$ ribosomal subunit, $26 \mathrm{~s} \mathrm{rRNA}=26 \mathrm{~s}$ ribosomal subunit, $\mathrm{ACT}=$ actin, ACT-1 = actin-1, APT = adenine phosphoribosyltransferase, CYP = cyclophilin, EF = elongation factor, EF-1 = elongation factor 1 , GADPH = glyceraldehyde-3phosphate dehydrogenase, $\mathrm{L} 2=$ ribosomal protein $\mathrm{L} 2, \mathrm{PL}=$ pectate lyase, $\mathrm{RPS} 2=$ ribosomal protein $\mathrm{S} 2, \mathrm{RPS} 4=$ ribosomal protein $\mathrm{S} 4, \mathrm{TUA}=\alpha$-tubulin, UBQ $=$ ubiquitin, and UBQ2 = ubiquitin 2 
several defense-related genes that are strongly induced in resistant Calcutta 4 and downregulated or not induced in susceptible Williams during the early biotrophic phase of the infection process.

In addition to identifying genes that are induced during infection, this effort also identified reference genes for expression analysis. Reference genes are widely used as internal controls in a variety of gene expression studies (Pfaffl et al. 2004) and, although a large number of reference genes have been used in plants (BarsalobresCavallari et al. 2009; Lilly et al. 2011; Takle et al. 2007), it is necessary to determine the most suitable reference gene for each species. qRT-PCR was used to validate the microarray results (Die et al. 2010; Kubista et al. 2006; Mahomed and van den Berg 2011).

Previously, several different reference genes have been used in banana for gene expression studies concerned with development, fruit maturation, response to hormone treatments, and stresses such as osmotic, chilling, disease, and high temperature (Chen et al. 2011; Podevin et al. 2012). However, stability of banana reference genes may vary under different experimental conditions (Podevin et al. 2012); therefore, candidate genes should be carefully analyzed and validated in the context of each experimental question.

Results found in the present work indicated that 26S ribosomal subunit and $18 \mathrm{~S}$ ribosomal subunit are the best housekeeping internal reference genes for expression studies under the experimental conditions used herein. Actin has been used commonly as a reference gene in several pathosystems; however, this gene showed high variability in our analysis. Henty-Ridilla et al. (2013) observed a role for actin in cytoskeleton remodeling during pathogen infection. Therefore, actin was not appropriate as a reference gene for this study.

Shortly after inoculation with $M$. fijiensis, expression of defenserelated genes showed contrasting values between resistant Calcutta 4 and susceptible Williams, with earlier and stronger gene expression observed in the resistant variety compared with the susceptible cultivar. These results are in agreement with observations of Portal et al. (2011), who identified late overexpression of PR-4 (30 days after inoculation) and cinnamate hydroxylase $(\mathrm{C} 4 \mathrm{H})(23$ days after inoculation) in susceptible Grande Naine inoculated with M. fijiensis. $\mathrm{C} 4 \mathrm{H}$, like PAL, is a key enzyme in the phenylpropanoid pathway which leads to the synthesis of several groups of metabolites involved in the plant defense systems such as the phytoalexins, lignin, flavonoids, coumarins, and others (Achnine et al. 2004; Hoss et al. 2000). Similarly, Torres et al. (2012) observed rapid induction of PAL, POX, and $\beta-1,3$-glucanase in Calcutta 4 at 6 to 18 hai, as well as the production of hydrogen peroxide at 72 hai; in contrast, induction of these genes in a susceptible cultivar did not occur until 6 days after inoculation. These results suggest that the first 72 hai are critical to the host's ability to limit pathogen invasion.

Genes coding for POX, DRR1, and PAL were clearly upregulated during the first 24 hai in resistant Calcutta 4 . The importance and role of POX, DDR1, and PAL proteins in the banana defense response has been addressed before (Torres et al. 2012). In resistant banana
Table 2. Repeated pairwise regression analysis of potential reference genes ${ }^{\mathrm{a}}$

\begin{tabular}{lcccccccc}
\hline & \multicolumn{3}{c}{ Calcutta 4 } & & \multicolumn{3}{c}{ Williams } \\
\cline { 2 - 3 } \cline { 7 - 8 } Analysis & GADPH & $\mathbf{1 8 S}$ & $\mathbf{2 6 S}$ & & GADPH & $\mathbf{1 8 S}$ & $\mathbf{2 6 S}$ \\
\hline PCC & 0.11 & 0.51 & 0.82 & & 0.78 & 0.89 & 0.63 \\
DC & 0.01 & 0.26 & 0.67 & & 0.61 & 0.79 & 0.40 \\
Intercept & 21.55 & 0.91 & -13.62 & & 6.29 & -10.62 & -8.81 \\
Slope & 0.20 & 0.77 & 1.63 & & 0.94 & 1.21 & 1.22 \\
SD & \pm 0.788 & \pm 0.584 & \pm 0.516 & & \pm 0.511 & \pm 0.428 & \pm 1.016 \\
$P$ value & 0.623 & 0.018 & 0.001 & & 0.001 & 0.001 & 0.001 \\
HKG (x-fold) & 1.15 & 1.71 & 3.10 & & 1.92 & 2.32 & 2.33 \\
\hline
\end{tabular}

a All calculations were performed using the BestKeeper software with defaul parameters. For Pearson correlation coefficient (PCC), determination coefficient (DC), and $P$ value, data from 21 samples were used. The intercept, slope, and standard deviation (SD) were calculated based on the crossing point $(\mathrm{CP})$ values.

b Power of housekeeping gene (HKG). Values showing the best expression stability are those with the power of HKG closer to threefold.

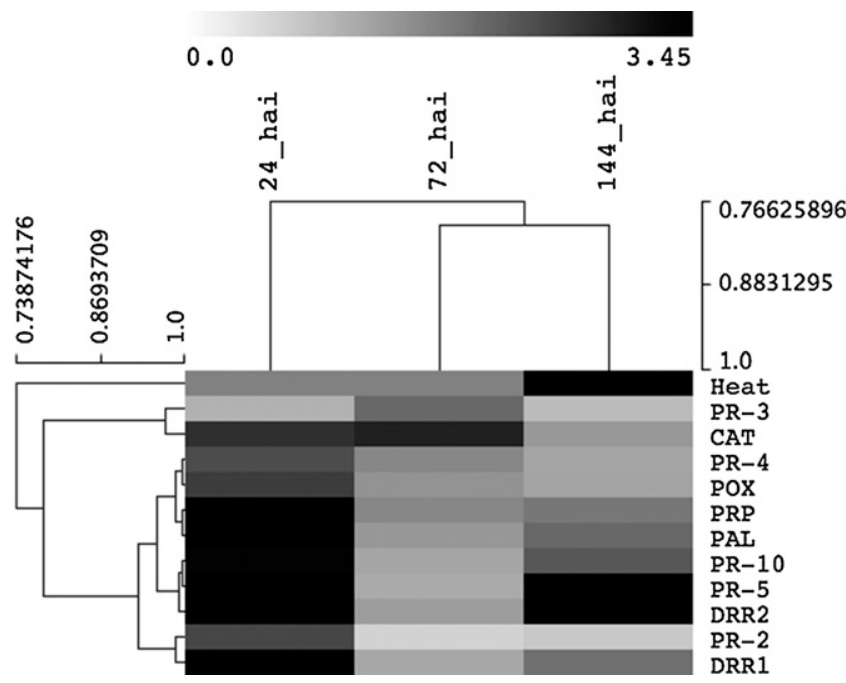

Fig. 3. Hierarchical clustering analysis of representative potential defense genes selected from the microarrays. Image represents significant $(P<0.05)$ average expression differences between Calcutta 4 without inoculation (control) and Calcutta 4 at 24, 72, and $144 \mathrm{~h}$ after inoculation (hai) with Mycosphaerella fijiensis from three independent experiments. Analysis was performed using Multiple Array Viewer Software, version 4.8.1. The gray-scale bars represent gene expression changes, ranging from suppressed (light gray) to upregulated (black). Heat $=$ heat shock protein, PR-3 = pathogenesis-related protein 3, CAT = catalase, PR-4 = pathogenesisrelated protein $4, \mathrm{POX}=$ peroxidase, $\mathrm{PRP}=$ pathogenesis-related protein 1 , $\mathrm{PAL}=$ phenylalanine ammonia-lyase, $\mathrm{PR}-10=$ pathogenesis-related protein $10, \mathrm{PR}-5=$ pathogenesis-related protein $5, \mathrm{DRR} 1=$ disease resistance response 1 , and DRR2 $=$ disease resistance response 2 .

Table 1. Results of quantitative reverse-transcription polymerase chain reaction (PCR) of expression of constitutively expressed reference genes in Calcutta 4 and Williams banana

\begin{tabular}{|c|c|c|c|c|c|c|c|c|}
\hline \multirow[b]{2}{*}{ Parameters $^{\mathbf{a}}$} & \multicolumn{4}{|c|}{ Calcutta 4} & \multicolumn{4}{|c|}{ Williams } \\
\hline & GADPH & $18 \mathrm{~s}$ & $26 s$ & Actin & GADPH & $18 \mathrm{~s}$ & $26 s$ & Actin \\
\hline$N$ & 21 & 21 & 21 & 21 & 21 & 21 & 21 & 21 \\
\hline geo Mean $(\mathrm{CP})$ & 25.04 & 14.4 & 14.8 & 30.5 & 25.0 & 13.5 & 15.4 & 30.1 \\
\hline ar Mean $(\mathrm{CP})$ & 25.05 & 14.4 & 14.9 & 30.6 & 25.0 & 13.5 & 15.4 & 30.1 \\
\hline $\operatorname{Min}(\mathrm{CP})$ & 23.80 & 12.9 & 13.1 & 27.6 & 23.8 & 12.2 & 13.7 & 26.8 \\
\hline Max (CP) & 26.51 & 15.6 & 16.6 & 33.3 & 27.0 & 15.2 & 17.9 & 32.9 \\
\hline $\mathrm{SD}( \pm \mathrm{CP})$ & 0.71 & 0.5 & 0.7 & 2.1 & 0.6 & 0.8 & 1.0 & 1.8 \\
\hline $\mathrm{CV}(\% \mathrm{CP})$ & 2.84 & 3.4 & 4.7 & 6.7 & 2.4 & 5.6 & 6.3 & 6.1 \\
\hline Min (x-fold) & -2.36 & -2.8 & -3.3 & -7.9 & -2.3 & -2.5 & -3.2 & -9.9 \\
\hline Max (x-fold) & 2.77 & 2.4 & 3.3 & 6.9 & 3.9 & 3.3 & 5.8 & 7.1 \\
\hline $\mathrm{SD}( \pm \mathrm{x}$-fold $)$ & 1.64 & 1.4 & 1.6 & 4.2 & 1.5 & 1.7 & 2.0 & 3.6 \\
\hline
\end{tabular}

a Parameters of PCR assays. $N=$ number of samples, $\mathrm{CP}=$ critical point, geo Mean $(\mathrm{CP})=$ the geometric mean of $\mathrm{CP}$, ar $\mathrm{Mean}(\mathrm{CP})=$ the arithmetic mean of $\mathrm{CP}$, Min $(\mathrm{CP})$ and Max $(\mathrm{CP})=$ the extreme values of $\mathrm{CP}, \mathrm{SD}( \pm \mathrm{CP})=$ the standard deviation of the $\mathrm{CP}, \mathrm{CV}(\% \mathrm{CP})=$ the coefficient of variance expressed as a percentage on the $\mathrm{CP}$ level, Min (x-fold) and Max (x-fold) $=$ the extreme values of expression levels expressed as an absolute $\mathrm{x}$-fold over- or underregulation coefficient, and SD $( \pm \mathrm{x}$-fold $)=$ standard deviation of the absolute regulation coefficients. 
genotypes inoculated with M. fijiensis, PAL and POX have been correlated with defense processes mediated by secondary metabolites such as phytoalexins, although a cause-and-effect relationship for PAL in defense against the black leaf streak pathogen has not been

\section{PR-10}

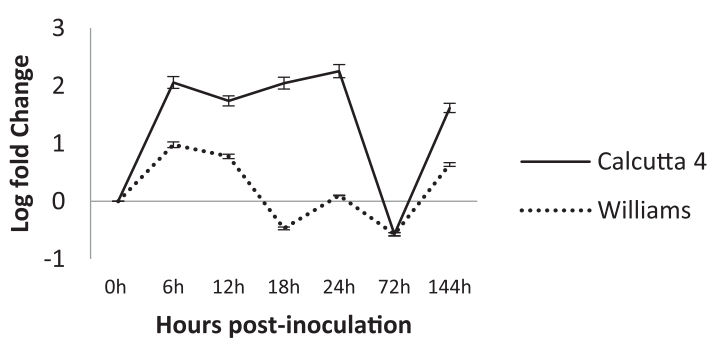

PAL

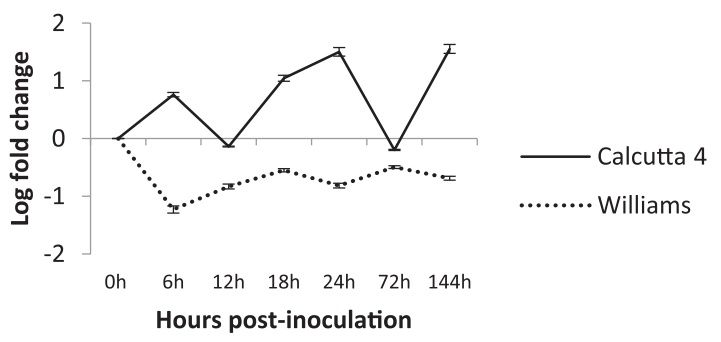

DRR1

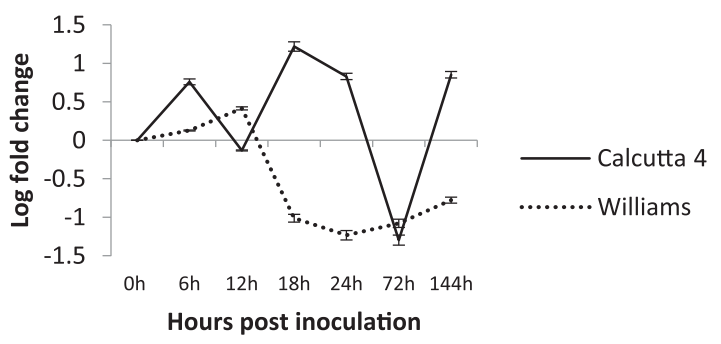

PR-4

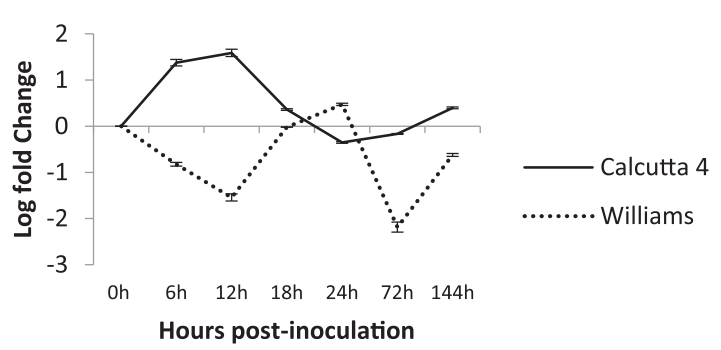

POX

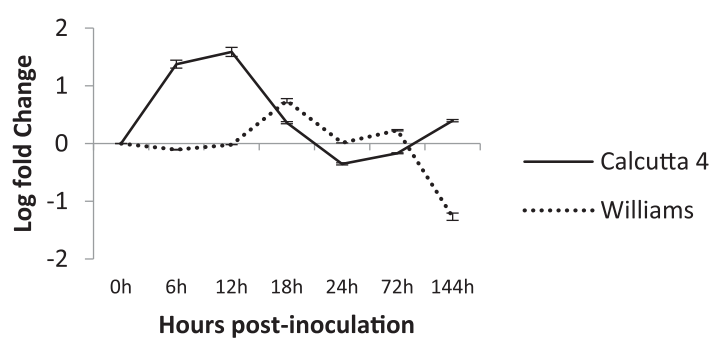

Fig. 4. Expression values of defense-related genes in Musa acuminata Colla in resistant Calcutta 4 and susceptible Williams after inoculation with the black leaf streak pathogen Mycosphaerella fijiensis M. Morelet. Bars represent the standard error of the mean calculated from three biological replicates in two independent experiments. PR-4 = pathogenesisrelated protein $4, \mathrm{DRR} 1=$ disease resistance response $1, \mathrm{PR}-10=$ pathogenesis-related protein $10, \mathrm{PAL}=$ phenylalanine ammonia-lyase, and $\mathrm{POX}=$ peroxidase . clearly established (Otálvaro et al. 2002; Torres et al. 2012). Upregulation of PAL, POX, and DRR1 has been correlated with lignin accumulation and cell wall thickening (Hoss et al. 2000; Khan et al. 2003). In addition, DDR1 has been implicated as part of the ligninbased Casparian strip domain protein machinery in Arabidopsis thaliana (L.) Heynh (Hosmani et al. 2013; Zhu et al. 2007).

PR-4 and PR-10 were also shown to be induced shortly after the pathogen inoculation. PR-4 has been shown to have antifungal activity, attributed to its ability to disrupt cell polarity by binding to chitin in the fungal cell wall (Bormann et al. 1999; Portal et al. 2011). PR-10 has exhibited ribonuclease and antifungal activity against pathogens isolated from Arachis hypogaea L., Jatropha curcas L., and Crocus sativus L. plants (Agarwal et al. 2013; Chadha and Das 2006; Gómez-Gómez et al. 2011).

Early detection of pathogen components such as pathogenassociated molecular patterns and effector proteins and induction of plant defense-related genes has been linked with plant resistant phenotypes (Jones and Dangl 2006). Most genes that were found regulated in the present study have been reported as components of early defense responses in other plants such as Arabidopsis thaliana. In Musa sp. genotypes, similar gene induction patterns have been identified in response to the pathogenic fungus causing fruit anthracnose (Colletotrichum musae (Berk. \& M. A. Curtis) Arx) or plant wilt (Fusarium oxysporum Schltdl.) (Sun et al. 2013; Tang et al. 2013), further supporting a role in the plant defense system for these genes.

In conclusion, this effort established that, shortly after infection, there is differential expressions of defense-related genes among resistant and susceptible banana cultivars inoculated with $M$. fijiensis, with clear early induction of several genes only in the resistant genotype. This phenomenon reinforces the notion that early recognition is important for resistance in this pathosystem. Detection of early induced defense-related genes might be useful in breeding programs for the selection of black-leaf-streak-resistant cultivars and for the identification and monitoring of materials that could act as elicitors of defense. Furthermore, we conclude that $26 \mathrm{~S}$ ribosomal subunit and $18 \mathrm{~S}$ ribosomal subunit are useful reference genes and that detection of overexpression of POX, PR-4, PR-10, PAL, and DRR1 are indicative of the activation of defense responses in the banana$M$. fijiensis interaction.

\section{Acknowledgments}

This work was supported by Instituto para el desarrollo de la Ciencia y la Tecnología Francisco José de Caldas (Colciencias), Colombia, project grant number 2213-452-21253; Dirección de Investigaciones Medellín (DIME) from Universidad Nacional de Colombia sede Medellín, project grant number 20101006122 and the institutions Corporación para Investigaciones Biológicas (CIB), Asociación de Bananeros de Colombia (Cenibanano-AUGURA), and Biointeractions \& Plant Health, Plant Research International.

\section{Literature Cited}

Achnine, L., Blancaflor, E. B., Rasmussen, S., and Dixon, R. A. 2004 Colocalization of L-phenylalanine ammonia-lyase and cinnamate 4-hydroxylase for metabolic channeling in phenylpropanoid biosynthesis. Plant Cell 16: 3098-3109.

Agarwal, P., Bhatt, V., Singh, R., Das, M., Sopory, S. K., and Chikara, J. 2013. Pathogenesis-related gene, JcPR-10a, from Jatropha curcas exhibit RNase and antifungal activity. Mol. Biotechnol. 54:412-425.

Alvarez, J. C., Rodriguez, H. A., Rodriguez-Arango, E., Monsalve, Z. I., Morales, O. J. G., and Arango, I. R. E. 2013. Characterization of a differentially expressed phenylalanine ammonia-lyase gene from banana induced during Mycosphaerella fijiensis infection. J. Plant Stud. 2:35-46.

Barsalobres-Cavallari, C. F., Severino, F. E., Maluf, M. P., and Maia, I. G. 2009 Identification of suitable internal control genes for expression studies in Coffea arabica under different experimental conditions. BMC Mol. Biol. 10:1

Bolstad, B. M., Irizarry, R. A., Astrand, M., and Speed, T. P. 2003. A comparison of normalization methods for high density oligonucleotide array data based on bias and variance. Bioinformatics 19:185-193.

Bormann, C., Baier, D., Hörr, I., Raps, C., Berger, J., Jung, G., and Schwarz, H. 1999. Characterization of a novel, antifungal, chitin-binding protein from Streptomyces tendae Tü901 that interferes with growth polarity. J. Bacteriol. 181:7421-7429.

Brazma, A., Hingamp, P., Quackenbush, J., Sherlock, G., Spellman, P., Stoeckert, C., Aach, J., Ansorge, W., Ball, C. A., Causton, H. C., Gaasterland, T. Glenisson, P., Holstege, F. C., Kim, I. F., Markowitz, V., Matese, J. C., 
Parkinson, H., Robinson, A., Sarkans, U., Schulze-Kremer, S., Stewart, J., Taylor, R., Vilo, J., and Vingron, M. 2001. Minimum information about a microarray experiment (MIAME) - toward standards for microarray data. Nat. Genet. 29:365-371.

Carvalho, B., and Irizarry, R. 2010. A framework for oligonucleotide microarray preprocessing. Bioinformatics 26:2363-2367.

Cavalcante, M. de J. B., Escoute, J., Madeira, J. P., Romero, R. E., Nicole, M. R., Oliveira, L. C., Hamelin, C., Lartaud, M., and Verdell, J. L. 2011. Reactive oxygen species and cellular interactions between Mycosphaerella fijiensis and banana. Trop. Plant Biol. 4:134-143.

Chadha, P., and Das, R. H. 2006. A pathogenesis related protein, AhPR10 from peanut: An insight of its mode of antifungal activity. Planta 225:213-222.

Chen, L., Zhong, H., Kuang, J., Li, J., Lu, W., and Chen, J. 2011. Validation of reference genes for RT-qPCR studies of gene expression in banana fruit under different experimental conditions. Planta 234:377-390.

Churchill, A. C. L. 2011. Mycosphaerella fijiensis, the black leaf streak pathogen of banana: Progress towards understanding pathogen biology and detection, disease development, and the challenges of control. Mol. Plant Pathol. 12:307-328.

D'Hont, A., Denoeud, F., Aury, J.-M., Baurens, F.-C., Carreel, F., Garsmeur, O., Noel, B., Bocs, S., Droc, G., Rouard, M., Da Silva, C., Jabbari, K., Cardi, C., Poulain, J., Souquet, M., Labadie, K., Jourda, C., Lengellé, J., Rodier-Goud, M., Alberti, A., Bernard, M., Correa, M., Ayyampalayam, S., Mckain, M. R., Leebens-Mack, J., Burgess, D., Freeling, M., Mbéguié-A-Mbéguié, D., Chabannes, M., Wicker, T., Panaud, O., Barbosa, J., Hribova, E. HeslopHarrison, P., Habas, R., Rivallan, R., Francois, P., Poiron, C., Kilian, A., Burthia, D., Jenny, C., Bakry, F., Brown, S., Guignon, V., Kema, G., Dita, M., Waalwijk, C., Joseph, S., Dievart, A., Jaillon, O., Leclercq, J., Argout, X., Lyons, E., Almeida, A., Jeridi, M., Dolezel, J., Roux, N., Risterucci, A.-M., Weissenbach, J., Ruiz, M., Glaszmann, J.-C., Quétier, F., Yahiaoui, N., and Wincker, P. 2012. The banana (Musa acuminata) genome and the evolution of monocotyledonous plants. Nature 488:213-217.

Die, J. V., Román, B., Nadal, S., and González-Verdejo, C. I. 2010. Evaluation of candidate reference genes for expression studies in Pisum sativum under different experimental conditions. Planta 232:145-153.

Falcon, S., Carvalho, B., Carey, V., Settles, M., and Beuf, K. 2009. pdInfoBuilder: Platform Design Information Package Builder. R package version 1.22.0. Online publication. http://www.bioconductor.org/packages/release/bioc/html/ pdInfoBuilder.html

Fouré, E. 1987. Varietal reactions of bananas and plantains to black leaf streak disease. Pages 110-113 in: Banana and Plantain Breeding Strategies: Proc. Int. Workshop. G. J. Persley and E. A. De Langhe, eds. ACIAR, Cairns, Australia.

Gentleman, R. C., Carey, V. J., Bates, D. M., Bolstad, B., Dettling, M., Dudoit, S., Ellis, B, Gautier, L., Ge, Y., Gentry, J., Hornik, K., Hothorn, T., Huber, W., Iacus, S., Irizarry, R., Leisch, F., Li, C., Maechler, M., Rossini, A. J., Sawitzki, G., Smith, C., Smyth, G., Tierney, L., Yang, J. Y., and Zhang, J. 2004. Bioconductor: Open software development for computational biology and bioinformatics. Genome Biol. 5:R80.

Gómez-Gómez, L., Rubio-Moraga, A., and Ahrazem, O. 2011. Molecular cloning and characterization of a pathogenesis-related protein CsPR10 from Crocus sativus. Plant Biol. 13:297-303.

Henty-Ridilla, J. L., Shimono, M., Li, J., Chang, J. H., Day, B., and Staiger, C. J. 2013. The plant actin cytoskeleton responds to signals from microbe-associated molecular patterns. PLoS Pathog. 9:e1003290.

Hosmani, P., Kamiya, T., Danku, J., Naseer, S., Geldner, N., Guerinot, M. L., and Salt, D. E. 2013. Dirigent domain-containing protein is part of the machinery required for formation of the lignin-based Casparian strip in the root. Proc. Natl. Acad. Sci. USA 110:14498-14503.

Hoss, R., Helbig, J., and Bochow, H. 2000. Function of host and fungal metabolites in resistance response of banana and plantain in the black Sigatoka disease pathosystem (Musa spp.- Mycosphaerella fijiensis). J. Phytopathol. 148:387-394. Jones, J. D. G., and Dangl, J. L. 2006. The plant immune system. Nature 444:323-329.

Khan, W., Prithiviraj, B., and Smith, D. L. 2003. Chitosan and chitin oligomers increase phenylalanine ammonia-lyase and tyrosine ammonia-lyase activities in soybean leaves. J. Plant Physiol. 160:859-863.

Kubista, M., Andrade, J. M., Bengtsson, M., Forootan, A., Jonák, J., Lind, K., Sindelka, R., Sjöback, R., Sjögreen, B., Strömbom, L., Ståhlberg, A., and Zoric, N. 2006. The real-time polymerase chain reaction. Mol. Aspects Med. 27:95-125.

Lilly, S. T., Drummond, R. S. M., Pearson, M. N., and MacDiarmid, R. M. 2011. Identification and validation of reference genes for normalization of transcripts from virus-infected Arabidopsis thaliana. Mol. Plant-Microbe Interact. 24:294-304.

Mahomed, W., and van den Berg, N. 2011. EST sequencing and gene expression profiling of defence-related genes from Persea americana infected with Phytophthora cinnamomi. BMC Plant Biol. 11:167.

Meredith, D. 1970. Banana leaf spot disease (Sigatoka) caused by Mycosphaerella musicola Leach. Phytopathol. Pap. 11:1-47.

Mira, J. J. 2004. Caracterización mediante métodos biológicos de aislamientos de Mycosphaerella fijiensis Morelet resistentes y sensibles a fungicidas utilizados en su manejo químico en la zona de Urabá (Colombia). Master of Science thesis,
Universidad Nacional de Colombia sede Medellín, Maestría en Ciencias Agrarias, Facultad de Ciencias Agrarias, Medellín, Colombia.

Ohm, R, A., Feau, N., Henrissat, B., Schoch, C. L., Horwitz, B. A., Barry, K. W. Condon, B. J., Copeland, A. C., Dhillon, B., Glaser, F., Hesse, C. N., Kosti, I., LaButti, K., Lindquist, E. A., Lucas, S., Salamov, A. A., Bradshaw, R. E., Ciuffettu, L., Hamelin, R. C., Kema, G. H. J., Lawrence, C., Scott, J. A., Spatafora, J. W., Turgeon, B. G., de Wit, P. J., Zhong, S., Goodwin, S. B., and Grigoriev, I. V. 2012. Diverse lifestyles and strategies of plant pathogenesis encoded in the genomes of eighteen Dothideomycetes fungi. PLoS Pathog. 8:e1003037.

Otálvaro, F., Echeverri, F., Quiñones, W., Torres, F., and Schneider, B. 2002 Correlation between phenylphenalenone phytoalexins and phytopathological properties in Musa and the role of a dihydrophenyl phenalenetriol. Molecules 7:331-340.

Pfaffl, M. W. 2001. A new mathematical model for relative quantification in realtime RTPCR. Nucleic Acids Res. 29:e45.

Pfaffl, M. W., Horgan, G. W., and Dempfle, L. 2002. Relative expression software tool (REST) for group-wise comparison and statistical analysis of relative expression results in real-time PCR. Nucleic Acids Res. 30:e36.

Pfaffl, M. W., Tichopad, A., Prgomet, C., and Neuvians, T. P. 2004. Determination of stable housekeeping genes, differentially regulated target genes and sample integrity: BestKeeper-Excel-based tool using pair-wise correlations. Biotechnol. Lett. 26:509-515.

Podevin, N., Krauss, A., Henry, I., Swennen, R., and Remy, S. 2012. Selection and validation of reference genes for quantitative RT-PCR expression studies of the non-model crop Musa. Mol. Breed. 30:1237-1252.

Portal, O., Izquierdo, Y., De Vleesschauwer, D., Sánchez-Rodríguez, A., MendozaRodríguez, M. Acosta-Suárez, M., Ocaña, B., Jiménez, E., and Höfte, M. 2011. Analysis of expressed sequence tags derived from a compatible Mycosphaerella fijiensis-banana interaction. Plant Cell Rep. 30:913-928.

Rodriguez Cabal, H. A. 2012. Analisis de la expresion de genes de la variedad banano 'Calcutta 4' (Musa AA) durante la interacción con Mycosphaerella fijiensis Morelet. Master of Science thesis, Universidad Nacional de Colombia sede Medellín, Maestría en Ciencias Agrarias, Facultad de Ciencias Agrarias, Medellín-Colombia.

Rozen, S., and Skaletsky, H. 2000. Primer3 on the WWW for general users and for biologist programmers. Pages 365-386 in: Bioinformatics Methods and Protocols. S. Misener and S. A. Krawetz, eds. Humana Press, Totowa, NJ.

Saeed, A. I., Sharov, V., White, J., Li, J., Liang, W., Bhagabati, N., Braisted, J., Klapa, M., Currier, T., Thiagarajan, M., Sturn, A., Snuffin, M., Rezantsev, A., Popov, D., Ryltsov, A., Kostukovich, E., Borisovsky, I., Liu, Z., Vinsavich, A., Trush, V., and Quackenbush, J. 2003. TM4: A free, open-source system for microarray data management and analysis. Biotechniques 34:374-378.

Smyth, G. K. 2004. Linear models and empirical Bayes methods for assessing differential expression in microarray experiments. Stat. Appl. Genet. Mol. Biol. 3:1-25.

Stergiopoulos, I., Cordovez, V., Ökmen, B., Beenen, H. G., Kema, G. H. J., and de Wit, P. J. G. M. 2013. Positive selection and intragenic recombination contribute to high allelic diversity in effector genes of Mycosphaerella fijiensis, causal agent of the black leaf streak disease of banana. Mol. Plant Pathol. 15:447-460.

Stover, R. H. 1980. Sigatoka leaf spot diseases of banana and plantain. Plant Dis. 64:750-755.

Sun, D., Lu, X., Hu, Y., Li, W., Hong, K., Mo, Y., Cahill, D. M., and Xie, J. 2013. Methyl jasmonate induced defense responses increase resistance to Fusarium oxysporum f. sp. cubense race 4 in banana. Sci. Hortic. (Amsterdam) 164: 484-491.

Takle, G. W., Toth, I. K., and Brurberg, M. B. 2007. Evaluation of reference genes for real-time RT-PCR expression studies in the plant pathogen Pectobacterium atrosepticum. BMC Plant Biol. 7:50.

Tang, Y., Kuang, J.-F., Wang, F.-Y., Chen, L., Hong, K.-Q., Xiao, Y.-Y., Xie, H., Lu, W.-J., and Chen, J.-Y. 2013. Molecular characterization of PR and WRKY genes during SA- and MeJA-induced resistance against Colletotrichum musae in banana fruit. Postharvest Biol. Technol. 79:62-68.

Torres, J. M., Calderón, H., Rodríguez-Arango, E., Morales, J. G., and Arango, R. 2012. Differential induction of pathogenesis-related proteins in banana in response to Mycosphaerella fijiensis infection. Eur. J. Plant Pathol. 133:887-898.

Vasquez, N., Tapia, A. C., and Galindo, J. 1990. Ultrastructural studies of the infection process of Mycosphaerella fijiensis on Musa cultivars. Pages 191-200 in: Sigatoka leaf spot disease in bananas: Proc. Int. Workshop, San José, Costa Rica. International Network for the Improvement of Banana and Plantain, Montpellier, France.

Zhu, L., Zhang, X., Tu, L., Zeng, F., Nie, Y., and Guo, X. 2007. Isolation and characterization of two novel dirigent-like genes highly induced in cotton (Gossypium barbadense and $G$. hirsutum) after infection by Verticillium dahliae. J. Plant Pathol. 89:41-45.

Zimmermann, P., Schildknecht, B., Craigon, D., Garcia-Hernandez, M., Gruissem, W., May, S., Mukherjee, G., Parkinson, H., Rhee, S., Wagner, U., and Hennig, L. 2006. MIAME/Plant-Adding value to plant microarrray experiments. Plant Methods 2:1. 